\title{
Primary pulmonary lymphoma in children
}

\author{
Xiaohui $\mathrm{Wu}^{1}$, Chunju Zhou' ${ }^{2}$ Ling $\mathrm{Jin}^{3}$, Hui Liu' ${ }^{1}$, Jinrong Liu ${ }^{1}$ and Shunying Zhao ${ }^{1 *}$
}

\begin{abstract}
Background: Primary pulmonary lymphoma (PPL) is a rare disease, especially in children. We analyse the clinical features of PPL in 4 children to strengthen a understanding of it.

Results: We reported a case series of 4 pediatric patients with PPLs including three diffuse large B-cell lymphomas and one natural killer-T cell lymphoma. All patients presented with unknown fever and cough as well as weight loss and fatigue. The white blood cell count was reduced in three patients and increased in the other one. The level of C-reactive protein was increased in all patients. The procalcitonin concentrations and bone marrow specimens were normal. Multiple or single pulmonary nodules with halo signs were found in all patients and air bronchograms found in 3 of them on chest computed tomography scan. Primary immunodeficiency was diagnosed in two patients who was performed genetic analysis.

Conclusions: When a patient presents with long-term fever, high C-reactive protein level, leukopenia/leukocytosis, and multiple or single pulmonary nodules with a "halo sign" and air bronchogram on computed tomography, a possibility of PPL should be considered. A co-existance of immunodeficiency needs to be further investigated in patients with PPL.
\end{abstract}

Keywords: Primary pulmonary lymphoma, Children, Immunodeficiency

\section{Background}

Malignant lymphomas are proliferative diseases of lymphoid tissue and are classified as Hodgkin lymphoma (HL) and non-Hodgkin lymphoma (NHL). Pulmonary lymphomas can be classified as primary (PPL) and secondary pulmonary lymphomas (SPL). Pulmonary lymphomas is defined as primary when they affect one or both lungs without any evidence of extra-pulmonary involvement for at least 3 months following the diagnosis. An exception to these criteria is when the lungs are the principal site of involvement (patients with satellite nodes can be considered to have PPL). PPL is rare, accounting for only $0.5-1 \%$ of primary pulmonary malignancies [1]. It most commonly occurs in adults (median age 60 years) and is particularly rare in children [2]. Here, we analyse clinical features of PPL to strengthen a better understanding of it.

\footnotetext{
* Correspondence: zhaoshunyingdoc@sina.com

'Department of Respiratory Medicine, Beijing Children's Hospital, Capital Medical University, Nanlishi Road 56, Xicheng District, Beijing, China Full list of author information is available at the end of the article
}

\section{Patients and methods}

Four patients were diagnosed with PPL between January 2009 and December 2017 in Department of Respiratory Medicine of Beijing Children's Hospital. All diagnoses were made by positive pathological findings of lung biopsies obtained surgically.

Data collected in this retrospective study included patient age, gender, main symptoms, medical history, chest $\mathrm{X}$-ray film, computed tomography (CT) scan, results of bone marrow biopsy, laboratory testing (blood counts, C-reactive protein $[\mathrm{CRP}]$ and procalcitonin $[\mathrm{PCT}]$ concentrations), and pathological results.

\section{Results}

\section{Clinical features}

Four patients had a median age of 8 years (range, 5-11 years) and comprised three boys and one girl. All patients have been misdiagnosed having pneumonia and had received anti-bacterial, anti-tuberculosis or anti-fungal treatment before the correct diagnosis was made. The mean interval between onset of symptoms and final diagnosis was 57 days (range 28-81 days). Four patients presented with fever and cough. Three patients had persistent high fever for more than 1 month, and one patient (No.1) had 
intermittent fever. All four patients had mild cough, weight loss and fatigue.

\section{Laboratory investigations}

The white blood cell count was reduced in three patients and increased in the other one. One patient had a slightly increased CRP level and the other three patients had remarkably increased CRP of greater than $100 \mathrm{mg} / \mathrm{L}$ (the normal range is $0-8 \mathrm{mg} / \mathrm{L}$ ). PCT concentrations were normal. All patients received bone marrow puncture and no abnormalities were found by morphological, immunological and cytological examinations. A bronchoalveolar lavage was performed in 3 of 4 patients ( $\mathrm{Pa}$ tient No. 2, 3 and 4). Neither the cytological or the microbiological examinations of bronchoalveolar lavage fluid had positive findings.

\section{Imaging manifestations}

All patients underwent chest radiographs and CT scans. Patient 1 had a single pulmonary mass $(3.7 \times 3.1 \mathrm{~cm})$ with air bronchograms (Fig. 1, 1A, 1B, 1C) whereas the remaining three patients had multiple nodules/masses (Fig. 12A,2B,2C,3A,3B,3C,4A,4B), with air bronchograms in two of them. All consolidated lesions had halo sign around.

\section{Pathological findings}

Pathological diagnoses were established by examination of biopsies obtained by open thoracotomy in three patients and thoracoscopy in one (Patient No.4). All patients were diagnosed as NHL, 3 patients had DLBCLs and one patients had extranodal natural killer (NK)-T cell lymphoma, nasal type (Fig. 2).

\section{Underlying disease}

Two patients were diagnosed with immunodeficiency. Patient No.1 had experienced frequent sinopulmonary infections starting from infancy, and the laboratory test showed a significant decrease in immunoglobulin (Ig) A and CD $4+$ cells $(\operatorname{IgA}<0.0667 \mathrm{~g} / \mathrm{L}, \mathrm{CD} 4+$ cells $6.1 \%)$. And

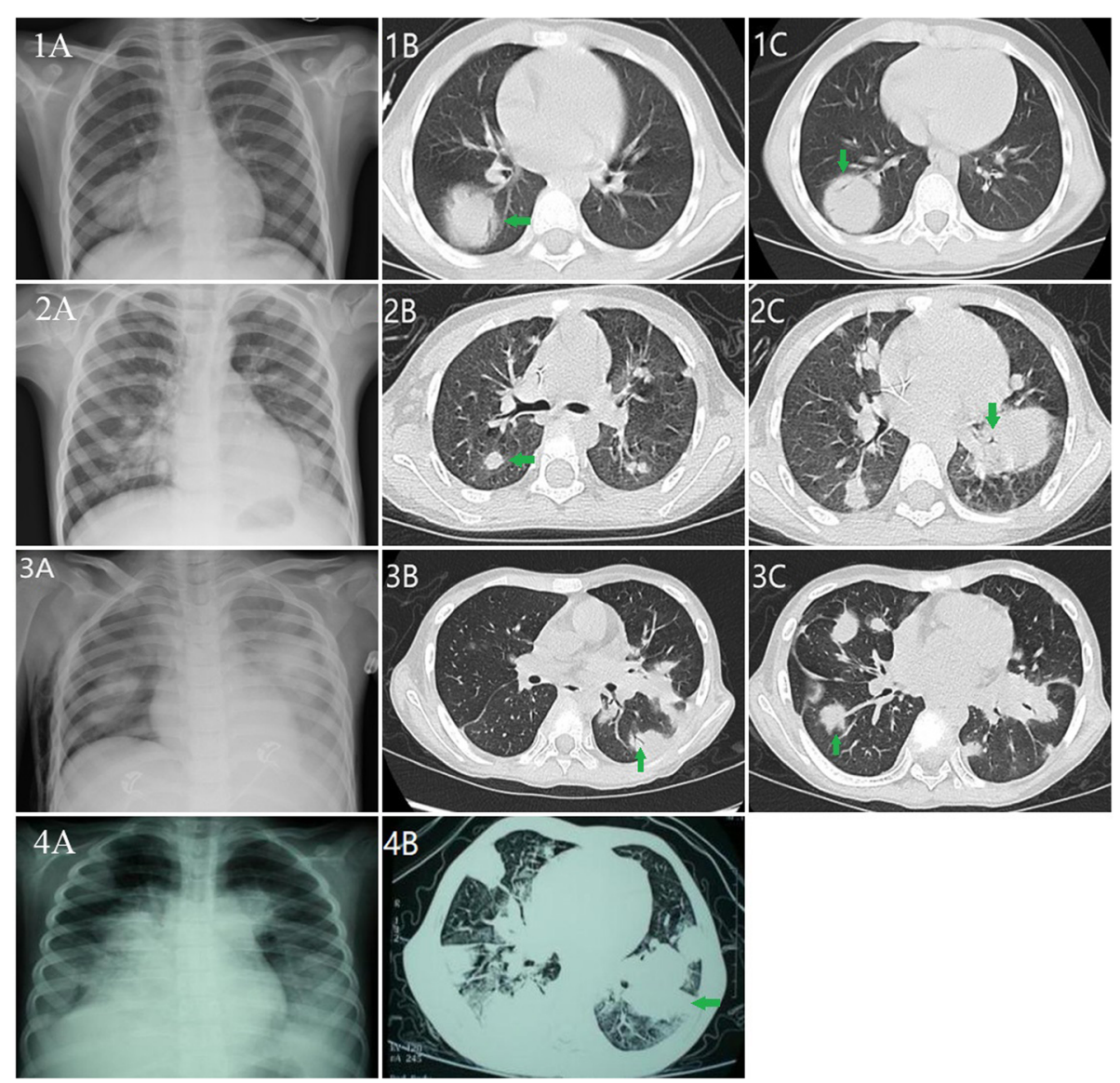

Fig. 1 Chest film and CT scan shows a circular consolidation $(3.7 \times 3.1 \mathrm{~cm})$ with poorly defined borders in the right lower lobe. An air bronchogram is readily seen (1a-c, Patient 1); Chest film and $C T$ image shows multiple nodular masslike areas of consolidation with halo signs and air bronchograms in both lungs (2a-c, Patient 2 and 3a-c, Patient 3); Chest film and CT image shows multiple nodular masslike areas of consolidation with halo signs in both lungs (4a-b, Patient 4) 


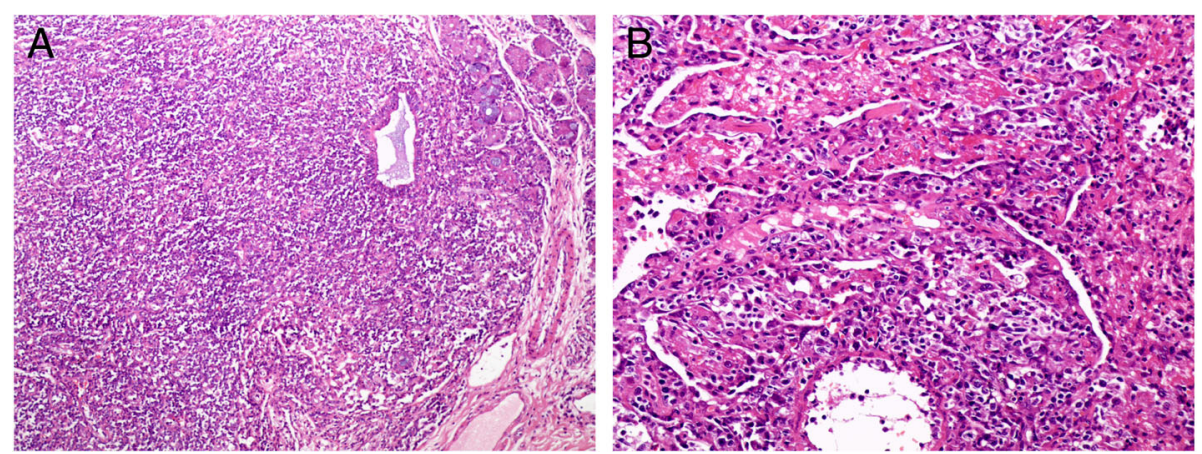

Fig. 2 The lesions showed extensive infiltration of atypical lymphlid cells. a Patient 1: DLBCL (HE,x 100); b Patient 3: NK/T-cell lymphoma (HE,× 200)

Table 1 Clinical features and laboratory features, genetic evaluation and prognosis of 4 patients with PPL

\begin{tabular}{|c|c|c|c|c|}
\hline & Patient 1 & Patient 2 & Patient 3 & Patient 4 \\
\hline Gender & Male & Male & Male & Female \\
\hline Age & 7-years-5-months & 5-years-2-months & 11-years-1-month & 8-years-4-months \\
\hline Presentation & Intermittent fever, cough & Persistent fever,cough & Persistent fever & Persistent fever \\
\hline Physical examination & Normal & Normal & Normal & Normal \\
\hline Past history & $\begin{array}{l}\text { History of recurrent pneumonia } \\
\text { (At the age of } 4 \text { months, } \\
\text { 2-years-old, 3-years-old, } \\
6 \text {-years-old and 7-years-old) }\end{array}$ & Normal & $\begin{array}{l}\text { History of recurrent } \\
\text { respiratory infections } \\
\text { (8-10 times per year) }\end{array}$ & Normal \\
\hline Underlying disease & I Ligase IV syndrome & Unclear & Immunodeficiency-21 & Unclear \\
\hline Prognosis & Died & Died & $\begin{array}{l}\text { Died of respiratory } \\
\text { failure after two } \\
\text { chemotherapy sessions }\end{array}$ & Died \\
\hline $\operatorname{WBC}\left(\times 10^{9} / \mathrm{L}\right)$ & $1.1 \sim 6.4$ & $2.1 \sim 7.8$ & $2.5 \sim 6.7$ & $4.3 \sim 8.8$ \\
\hline $\mathrm{CRP}(\mathrm{mg} / \mathrm{L})$ & $73 \sim 168$ & $5 \sim 23$ & $20 \sim 118$ & $120 \sim 180$ \\
\hline PCT (ng/ml) & Normal & Normal & Normal & Normal \\
\hline Pathological findings & Diffuse large B-cell lymphoma & $\begin{array}{l}\text { Diffuse large B-cell } \\
\text { lymphoma }\end{array}$ & NK/T-cell lymphoma & Diffuse large B-cell lymphoma \\
\hline Immune globulin & $\begin{array}{l}\lg A<0.0067 \mathrm{~g} / \mathrm{L}, \operatorname{lgG} 11.6 \mathrm{~g} / \mathrm{L} \\
\operatorname{lgM} 1.12 \mathrm{~g} / \mathrm{L}, \operatorname{lgE} 0.11 \mathrm{IU} / \mathrm{ml}\end{array}$ & Normal & Normal & Normal \\
\hline Lymphocyte subsets & $\begin{array}{l}\text { NK cells }(44.9 \%), \text { B cell } \\
(30.9 \%) ; \text { CD4+ cells }(6.1 \%), \\
\text { CD8+ cells }(19.6 \%)\end{array}$ & Normal & Normal & Normal \\
\hline ANA,dsDNA,ACA,ANCA & Normal & Normal & Normal & Normal \\
\hline $\begin{array}{l}\text { Bone marrow } \\
\text { examination }\end{array}$ & Normal & Normal & Normal & Normal \\
\hline Diagnostic procedure & Open lung biopsy & Open lung biopsy & Open lung biopsy & Thoracscopy lung biopsy \\
\hline $\begin{array}{l}\text { Cytological results } \\
\text { of bronchoalveolar } \\
\text { lavage fluid }\end{array}$ & - & $\begin{array}{l}\text { A great number of } \\
\text { neutrophils; A small } \\
\text { amounts of phagocytes, } \\
\text { epithelial cells and } \\
\text { lymphocytes; }\end{array}$ & $\begin{array}{l}\text { A great number of } \\
\text { neutrophils, A small } \\
\text { amounts of histiocytes, } \\
\text { epithelial cells and } \\
\text { lymphocytes; }\end{array}$ & $\begin{array}{l}\text { A great number of red blood } \\
\text { cells and neutrophis; A small } \\
\text { amounts of phagocytes, } \\
\text { epithelial cells and lymphocytes }\end{array}$ \\
\hline $\begin{array}{l}\text { Microbiological results } \\
\text { of bronchoalveolar } \\
\text { lavage fluid }\end{array}$ & - & Negative & Streptococcus viridans & Negative \\
\hline
\end{tabular}


the genetic tests (Next-Generation Sequencing technology) showed I Ligase IV syndrome. No abnormality in Igs and T-lymphocyte Subset was found in Patient No.3, but this boy had a history of recurrent respiratory infections, and his genetic examination showed immunodeficiency-21. Patient No.2 refused to take genetic test after the diagnosis of PPL. Patient No.4 did not receive genetic testing because the genetic testing technology was not widely used at the time of diagnosis.

\section{Treatment and outcome}

Patient No.3 diagnosed as extranodal NK-T cell lymphoma, nasal type received chemotherapy with SMILE regimen (Dexamethasone, Methotrexate, Ifosfamide, L-asparaginase, Etoposide). He achieved partial remission after the first course, but he got fever again and his pulmonary lesions progressed rapidly during the second course. Unfortunately, the boy died of respiratory failure after two chemotherapy sessions. The other three patients refused further treatment after diagnosis of PPL and died.

Clinical characteristics of 4 patients are shown in Table 1.

\section{Discussion}

We firstly reported PPL in children. There is difference in pathological type between children and adult. In adult studies, the most common type of PPL is mucosa-associated lymphoid tissue (MALT) lymphoma, an extranodal marginal zone lymphoma that accounts for $80-90 \%$ of PPL cases. DLBCL is the second most common type of PPL, and both MALT lymphoma and DLBCL are NHLs [3, 4]. However, DLBCL is the main pathological type in our study.

Patients with PPL may present with fever, cough, dyspnea, chest pain, hemoptysis, and other systemic symptoms (weight loss and fatigue) [4,5]. In our series, all patients had fever, cough and high CRP concentrations, which were similar to bacterial and fungal infection. These symptoms were nonspecific and contributed little to the diagnosis of PPL.

The radiological manifestations of lymphoma in the lung can be classified into four patterns: nodular, pneumonic or alveolar, bronchovascular or lymphangitic, and miliary nodules [6]. There may be two or more types in the same patient. The most common pattern of pulmonary lymphoma is nodules. Multiple bilateral lung nodules with air bronchograms are the commonest findings in PPL [7]. In this study, all patients had nodules/masses, three patients had air bronchograms. In addition, halo signs were found in all patients. The halo sign is mainly associated with invasive aspergillosis, but may be present in PPL patient. It is proposed that the halo sign is caused by invasion of lymphoma cells into the blood vessels with resultant bleeding into the surrounding tissue [4], or infiltration of tumor cells into the surrounding normal lung tissue [1].

NHL is a predominant malignancy in a number of primary immunodeficiency diseases. The incidence of NHL in immunodeficient patients was 59\%, and the incidence of immunodeficiency was $17.5 \%$ in NHL [8-10]. Although the mechnisms of the increased incidence of lymphoproliferative disease in immunodeficient patients are not fully understood, deterioration in immunoregulation, chronic antigenic stimulation, and tumor suppressor system dysregulation are thought to be the main explanation for it $[7,11,12]$. Two of the 4 patients in this study had immunodeficiency, suggesting that immunodeficiency disease need to be investigated in patients with PPL.

This study focuses on the diagnosis of PPL. All four patients in this study died, although one received chemotherapy. Treatment options and prognosis of PPL were still not clear.

\section{Conclusions}

When a patient presents with long-term fever, high C-reactive protein concentrations, leukopenia/leukocytosis, and multiple or single pulmonary nodules with a "halo sign" and air bronchogram on CT scan, a possibility of PPL should be considered. The co-existance of immunodeficiency disease needs to be investigated in patients with PPL.

\section{Abbreviations}

CRP: C-reactive protein; CT: Computed tomography; DLBCL: Diffuse large Bcell lymphoma; HL: Hodgkin Iymphoma; Ig: Immunoglobulin; MALT: Mucosaassociated derived lymphoma; NHL: Non-Hodgkin lymphoma;

PCT: Procalcitonin; PPL: Primary pulmonary lymphoma; SPL: Secondary pulmonary lymphomas

\section{Acknowledgments}

We thank Dr. Trish Reynolds, MBBS, FRACP, from Liwen Bianji, for editing the English text of a draft of this manuscript. We also thank all of the patients and their families for their kind cooperation.

Funding

There is no funding for this study.

Availability of data and materials

Please contact author for data requests.

\section{Authors' contributions}

XHW collected the data, and drafted the initial manuscript; CZ contributed to perform histopathology. $L, H L$ and JRL supervised the patient care and gave some advice on the revision of the manuscript. SYZ supervised the patient care, conceptualized the study, and reviewed and revised the manuscript. All authors read and approved the final manuscript.

\section{Ethics approval and consent to participate}

The protocol of this study received Ethics Committee approval from Beijing Children's Hospital.

Consent for publication

All patient guardians gave informed consent to the publication of this study. 


\section{Competing interests}

The authors declare that they have no competing interests.

\section{Publisher's Note}

Springer Nature remains neutral with regard to jurisdictional claims in published maps and institutional affiliations.

\section{Author details}

${ }^{1}$ Department of Respiratory Medicine, Beijing Children's Hospital, Capital Medical University, Nanlishi Road 56, Xicheng District, Beijing, China. 2Department of Pathology, Beijing Children's Hospital, Capital Medical University, Nanlishi Road 56, Xicheng District, Beijing, China. ${ }^{3}$ Hematology Oncology Center, Beijing Children's Hospital, Capital Medical University, Nanlishi Road 56, Xicheng District, Beijing, China.

Received: 18 September 2018 Accepted: 25 January 2019

Published online: 08 February 2019

\section{References}

1. Cardenas-Garcia J, Talwar A, Shah R, Fein A. Update in primary pulmonary lymphomas. Curr Opin Pulm Med. 2015;21(4):333-7.

2. Piña-Oviedo S, Weissferdt A, Kalhor N, Moran CA. Primary pulmonary lymphomas. Adv Anat Pathol. 2015;22(6):355-75.

3. Neri $\mathrm{N}$, Jesús NM, Avilés A. Diffuse large B-cell lymphoma primary of lung. Hematology. 2011;16(2):110-2.

4. Zhang J, Wang M, Yang X, Liu C, He X. Primary pulmonary extranodal NK/Tcell lymphoma of nasal type misdiagnosed as pneumonia: a case report and literature review. Medicine (Baltimore). 2017;96(49):e8914.

5. Kocatürk Ci, Seyhan EC, Günlüoğlu MZ, Urer N, Kaynak K, Dinçer Si, et al. Primary pulmonary non-Hodgkin's lymphoma: ten cases with a review of the literature. Tuberk Toraks. 2012:60(3):246-53.

6. Vargas HA, Hampson FA, Babar JL, Shaw AS. Imaging the lungs in patients treated for lymphoma. Clin Radiol. 2009;64(11):1048-55.

7. Sirajuddin A, Raparia K, Lewis VA, Franks TJ, Dhand S, Galvin JR, et al. Primary pulmonary lymphoid lesions: radiologic and pathologic findings. Radiographics. 2016;36(1):53-70.

8. Pulvirenti F, Pecoraro A, Cinetto F, Milito C, Valente M, Santangeli E, et al. Gastric Cancer is the leading cause of death in Italian adult patients with common variable immunodeficiency. Front Immunol. 2018;9:2546.

9. Mayor PC, Eng KH, Singel KL, Abrams SI, Odunsi K, Moysich KB, et al. Cancer in primary immunodeficiency diseases: Cancer incidence in the United States immune deficiency network registry. J Allergy Clin Immunol. 2018; 141(3):1028-35.

10. Tanyildiz HG, Dincaslan H, Yavuz G, Unal E, Ikinciogulları A, Dogu F, et al. Lymphoma secondary to congenital and acquired immunodeficiency syndromes at a Turkish pediatric oncology center. J Clin Immunol. 2016; 36(7):667-76.

11. Yoshino N, Hirata T, Takeuchi C, Usuda J, Hosone M. A case of primary pulmonary diffuse large B-cell lymphoma diagnosed by transbronchial biopsy. Ann Thorac Cardiovasc Surg. 2015;21(4):396-8.

12. Borie R, Wislez M, Thabut G, Antoine M, Rabbat A, Couderc LJ, et al. Clinical characteristics and prognostic factors of pulmonary MALT Iymphoma. Eur Respir J. 2009;34(6):1408-16.

Ready to submit your research? Choose BMC and benefit from:

- fast, convenient online submission

- thorough peer review by experienced researchers in your field

- rapid publication on acceptance

- support for research data, including large and complex data types

- gold Open Access which fosters wider collaboration and increased citations

- maximum visibility for your research: over $100 \mathrm{M}$ website views per year

At $\mathrm{BMC}$, research is always in progress.

Learn more biomedcentral.com/submissions 